\section{Microanatomical Study of the Intracranial Abducens Nerve: Clinical Interest and Surgical Perspective}

\author{
İntrakranial Abdüsens Sinirinin \\ Mikroanatomik C̣alıșması: \\ Klinik ve Cerrahi Bakıș
}

\begin{abstract}
AIM: The microanatomy of the abducens nerve (AN) is important for clinical reasons and surgical approaches as it is located in the petroclival region. The incidence of branching and duplication of the abducens nerve are unknown and mechanisms relating to paralysis of the nerve in indirect conditions are yet to be clarified.

MATERIAL and METHODS: Microanatomical details (anatomical observations and morphometric measurements) of the AN were obtained from 20 cadaveric skull bases (40 specimens).

RESULTS: $55 \%$ of the intracranial abducens nerves had branching, with type 2 and 3 branching occurring in 10\%. The nerve coursed below the petrosphenoidal ligament in all but one, and was located at the lateral third below the ligament in $82.5 \%$ of the specimens. The mean AN diameter was $1.3 \pm 0.2 \mathrm{~mm}$, and the mean diameter of the dural entrance pore was $1.8 \pm 0.3 \mathrm{~mm}$, the right being significantly larger than the left. The mean distance of the AN from the posterior clinoid process was $8.4 \pm 2.5 \mathrm{~mm}$ and from the petrous apex $3.6 \pm 2.1 \mathrm{~mm}$.

CONCLUSION: Branching of the AN was present in a significant number of specimens; the branching pattern at the cavernous segment may be called "pseudobranching". The AN is at risk for paresis in indirect conditions because of its angles and fixations on its course.
\end{abstract}

KEYWORDS: Abducens nerve, Skull base surgery, Microanatomy

ÖZ

AMAÇ: Petroklival bölgede yer alan abdüsens sinirinin mikroanatomisi klinik sebepler ve cerrahi yaklaşımlar nedeniyle önem taşır. Sinirin dallanma ve duplikasyon insidansı bilinmememekte, aynı zamanda da indirekt olaylarda ortaya çıkan paralizi mekanizmalarının açıklığa kavuşturulması gerekmektedir. YÖNTEM ve GEREÇ: Abdüsens sinirinin mikroanatomik detayları (anatomik gözlemler ve morfometrik ölçümler 20 kadavra kafatabanında (40 örnekte) çalışıldı.

BULGULAR: Abdüsens sinirinin dallanma oranı belirgin ölçüde yüksek bulunmuştur. Kavernöz segmentteki dallanma "pseudobranching" (yalancı dallanma) olarak adlandırılabilir. Abdüsens siniri yol boyunca meydana gelen "açılanma ve fiksasyonlardan" dolayı indirekt durumlarda risk altında kalmaktadır.

SONUÇ: Abdüsens sinirinin dallanma oranı belirgin ölçüde yüksek bulunmuştur. Kavernöz segmentteki dallanma "pseudobranching" (yalancı dallanma) olarak adlandırılabilir. Abdüsens siniri yol boyunca meydana gelen "açılanma ve fiksasyonlardan" dolayı indirekt durumlarda risk altında kalmaktadır. $\mathrm{Bu}$ çalışmayla sağlanan morfometrik bilgiler cerrahi yaklaşımlarda kolaylık sağlayabilir.

ANAHTAR SÖZCÜKLER: Abdüsens siniri, Kafatabanı cerahisi, Mikroanatomi

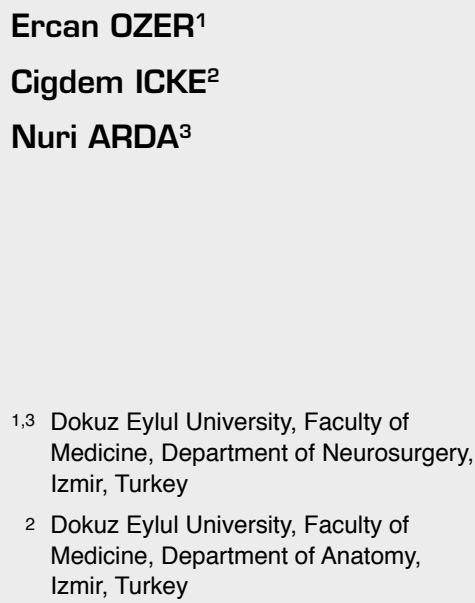
Medicine, Department of Neurosurgery, Izmir, Turkey

2 Dokuz Eylul University, Faculty of Medicine, Department of Anatomy, Izmir, Turkey

Received : 23.03.2010

Accepted : 22.07.2010

Correspondence address: Ercan OZER

Dokuz Eylül Üniversitesi, Tıp Fakültesi, Nöroşirürji Anabilim Dalı, 35340 incirialtı, İzmir, TURKEY Phone : +90 5056985798

Fax : : +90 2322788802

E-mail : ercozer@yahoo.com 


\section{INTRODUCTION}

The complexity of human anatomy reaches its apogee in the skull base where surgical interventions have been increasingly performed in the last years. Exact knowledge of the microanatomy is essential for those performing procedures in the area of the skull base. Recent studies of the bony, connective, vascular, and nervous structures of the skull base have allowed for significant advances in microneurosurgical techniques $(3,11,14,34,35,37)$. The abducens nerve (AN), cranial nerve VI, innervates the lateral rectus muscle of the eye, which turns the eye laterally. The AN leaves the brain stem and enters the dura at the base of the skull, where it courses through Dorello's canal before entering the cavernous sinus. The AN and its anatomy are important as it passes through Dorello's canal in the petroclival area, an important region for skull base surgery and interventions. The AN may be affected directly or indirectly in a variety of pathological disorders, including trauma, intracranial hypertension, skull base tumors, and vascular and inflammatory conditions $(4,27,30,31,41,45)$.

Although comprehensive studies regarding AN in Dorello's canal and in the sphenopetroclival area have been performed $(13,15,30,40,42)$, its incidence of branching and duplication are uncertain. The mechanisms of the conditions resulting in the AN becoming paralyzed indirectly are also yet to be clarified. The microanatomical details of the intracranial abducens nerve before the cavernous sinus are presented and discussed with respect to clinical findings and surgical approaches in this study.

\section{MATERIAL and METHODS}

This microanatomical study was carried out in the anatomy laboratory of our university medical center. Twenty cadaver heads (40 specimens) were used for the study. First, the calvaria of heads fixed in formaldehyde were removed. Brains were removed meticulously, with special attention to the cranial nerves. Microanatomical dissections were performed with a Zeiss OPMI surgical microscope (Carl Zeiss Co., Oberkochen, Germany). The AN was followed to where it passed through the dura, and the dura over Dorello's canal and the surrounding region were dissected. The AN and petrosphenoidal ligament were exposed. Microanatomical observations were made regarding the branching pattern, numbers of branches, and the relationship of the AN to the petrosphenoidal ligament. Using calipers, various morphometric measurements were made as can be seen in Figure 1: AN diameter, diameter of dural entrance 'pore' and distances between the AN and petrous apex (PA) and posterior clinoid process (PCP) at the level of the petrosphenoidal ligament. Measurements were made of both branches if branches were present. Statistical evaluations were performed using Student's t-test.

\section{RESULTS}

The branching patterns of the AN are shown in Table I. The AN was a single trunk in $18(45 \%)$ specimens, (Figure 1), whereas 55\% had branching along its course. Eight $(20 \%)$ specimens had double branching (Figure 2), and seven (17.5\%) had triple branching (Figure 3), which occurred only in the cavernous segment of the AN. In three (7.5\%) specimens, the branching starting at the cavernous segment continued through the superior orbital fissure (Figure 4). In relation to these cases, when branching of the AN occurred, no intervening tissue was found between the branches and the branches remained close to each other along their course. Four $(10 \%)$ specimens had branching at the petroclival segment at the level of the petrous angle (Figure 5). Branching at the petroclival segment occurred with tissue between the branches; the branches entered the dura separately and merged afterwards.

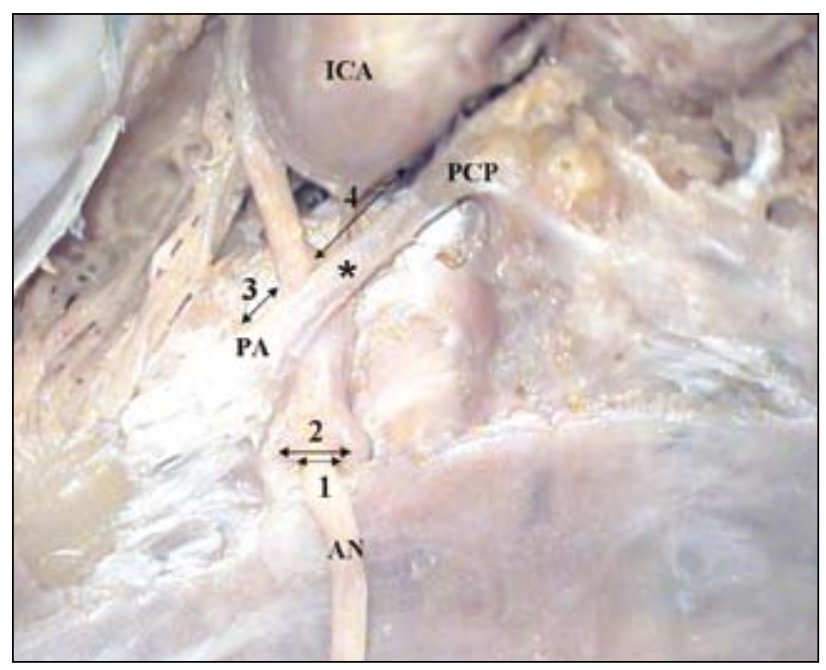

Figure 1: Right-sided specimen having a single trunk abducens nerve (AN) showing where morphometric measurements were taken: 1: AN diameter; 2: AN dural entering pore (DEP) diameter; 3: distance from the AN to the petrous apex (PA); and 4: distance from the $A N$ to the posterior clinoid process $(P C P)$. ICA: internal carotid artery. 


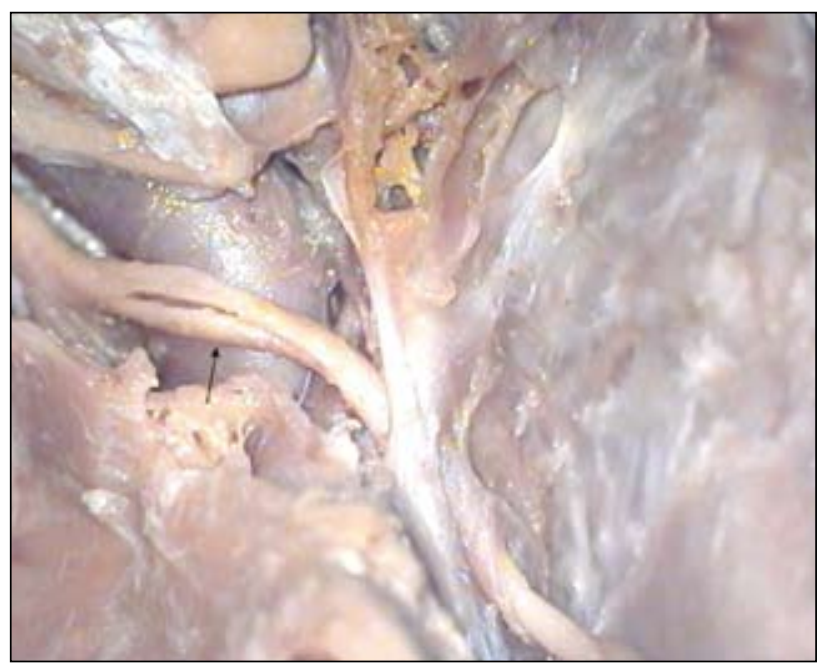

Figure 2: Double branching of the abducens nerve at the cavernous segment of the abducens nerve in a right-sided specimen (arrow). This type bifurcation of the nerve without intervening tissue was labeled "pseudobranching".

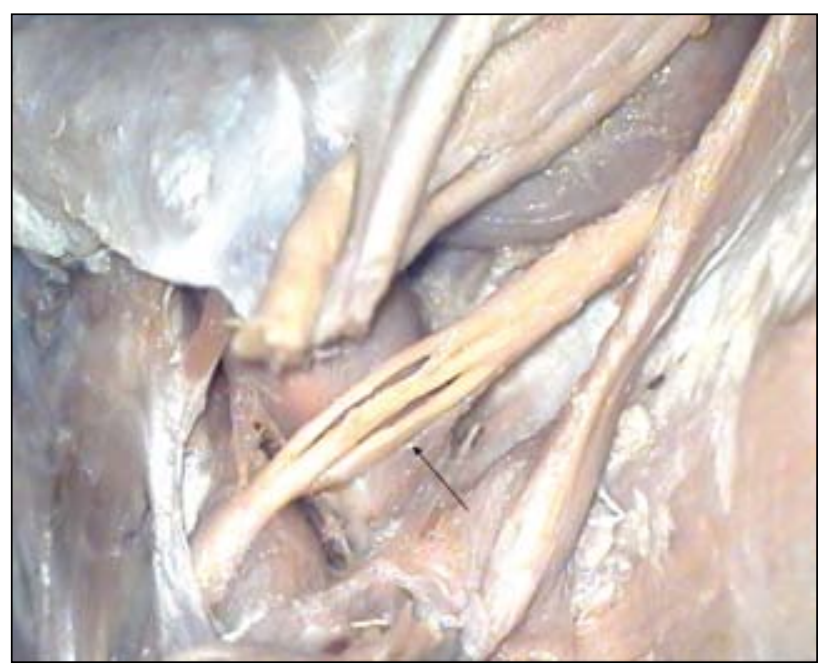

Figure 3: Triple branching of the abducens nerve at the cavernous segment in a left-sided specimen (arrow). As in "figure 2" it was labelled "pseudobranching", because there is no intervening tissue.

Duplication of the abducens nerve in its entirety was not encountered in any our specimens. In 10 (50\%) of the 20 skull bases, the same branching pattern was found bilaterally. The AN coursed over the petrosphenoidal ligament bilaterally in one case (two specimens, 5\%). This same skull had calcification of the petrosphenoidal ligament on both sides. The nerve coursed below the ligament in the remaining $38(95 \%)$ specimens. Regarding the course of the AN below the petrosphenoidal ligament, including the main trunks of branched nerves at the petroclival

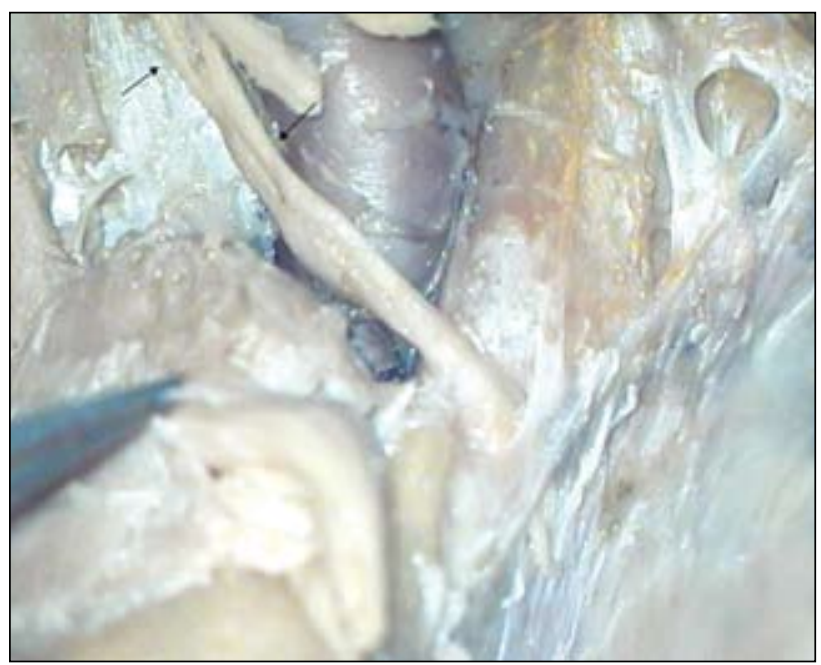

Figure 4: Branching of the cavernous segment of the abducens nerve in a right-sided specimen, which continues into the superior orbital fissure (arrows).

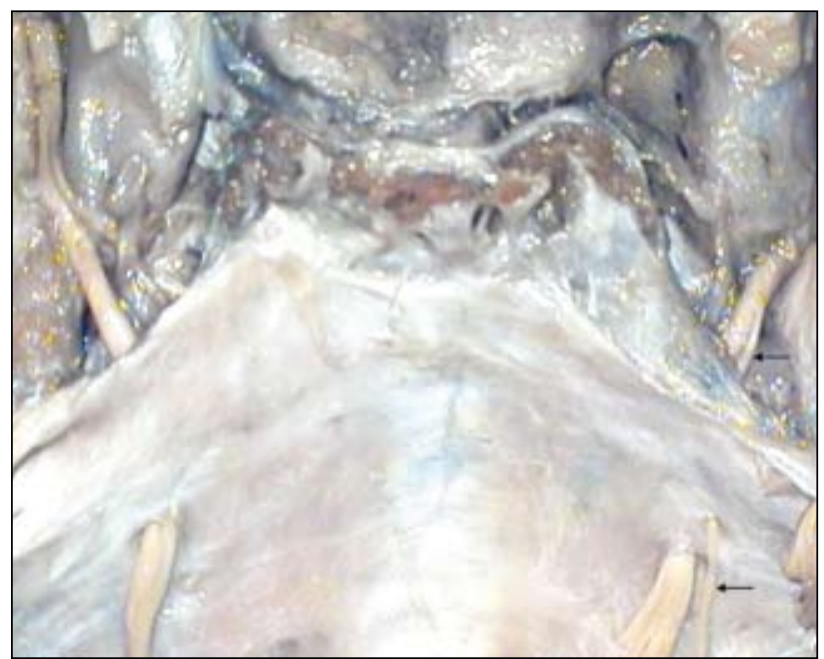

Figure 5: Branching of the petroclival segment of the abducens nerve on this left-sided specimen (arrows). Note that the branches of the nerve enter the dura separately.

segment, the AN travelled in the lateral third of the space near the petrous apex in the majority $(n=33$, $82.5 \%$ ) of specimens. The AN passed below the middle third of the petrosphenoidal ligament in 5 cases $(12.5 \%)$. The AN did not pass below the medial third of the petrosphenoidal ligament in any specimen. As regards the accessory branches of branched abducens nerves, two passed through the lateral third near the PA, one through the middle third and one through the medial third. All accessory branches coursed below the petrosphenoidal ligament. 
Table I: Branching Patterns of the Abducens Nerve in the Petroclival Region

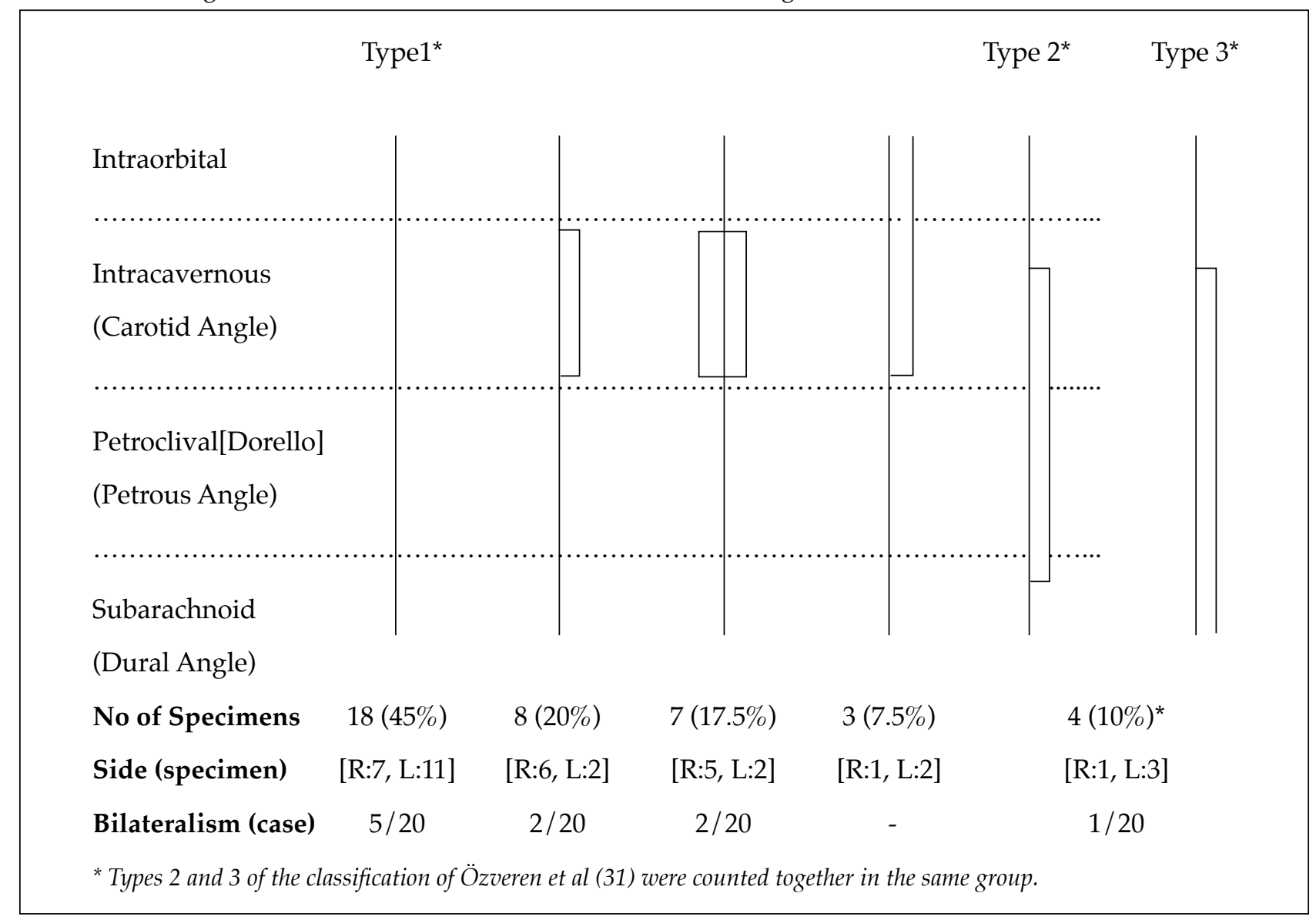

AN measurements and those of its dural entrance pores, including accessory abducens nerves (AAN), are listed in Table II. Right and left AN diameters were similar $(p=0.36)$. DEP diameters on the right side were significantly larger than those on the left $(\mathrm{p}=0.034)$. Mean, minumun and maximum lengths of measurements regarding distances between AN and the petrous apex (PA) and the posterior clinoid process (PCP) are shown in Table III; measurements relating to the AAN are listed separately. Differences between right and left sides of the AN to PCP $(\mathrm{p}=0.089)$ and $\mathrm{AN}$ to PA distances $(\mathrm{p}=0.37)$ were not statistically significant.

\section{DISCUSSION}

The abducens nerve (VI) has a long intracranial course and can therefore be affected by many medical disorders. It must also be taken into account during surgical procedures in the skull base area $(13,15,40,42)$. The subarachnoid segment of the AN emerges from the pontomedullary junction and ascends in a rostral and lateral direction to reach the petrous apex. It then pierces the visceral dura and turns medially and superiorly, and the petroclival segment of the nerve makes its "dural angle" here. It passes over the petrous apex below the petrosphenoidal ligament, called Dorello's canal, in its dural sheath. The AN travels through a venous space called the "petrovenous confluence". Downward and lateral angulation of the nerve at the petrous apex is called the "petrous angulation". Then, the AN enters the posteroinferior aspect of the cavernous sinus, and travels anteriorly from the lateral aspect of the internal carotid artery (ICA). The intracavernous segment of the abducens nerve makes a turn at this point, called the carotid angulation. The most severe angulation of the $\mathrm{AN}$ is at the petrous apex $(30,40,42,45)$.

Duplication of the abducens nerve has been described in studies concerning the $\mathrm{AN}$ and Dorello's canal $(15,16,28,31,40,42)$. Duplication of the nerve is important in when approaching the petroclival region with a drill, which can injure an unexpected second branch. The early intraoperative 
Table II: Diameters (mm) of the Abducens Nerve (AN), Accessory Abducens Nerve (AAN), and Dural Entrance Porus (DEP) in 20 Cadaveric Skulls

\begin{tabular}{|l|c|l|l|l|l|l|}
\hline & \multicolumn{3}{|c|}{ Diameter of the AN } & \multicolumn{3}{c|}{ DEP Diameter (AN) } \\
\hline & Right & Left & Both & Right & Left & Both \\
\hline Mean & $1.4 \pm 0.2$ & $1.3 \pm 0.2$ & $1.3 \pm 0.2$ & $1.9 \pm 0.3$ & $1.8 \pm 0.2$ & $1.8 \pm 0.3$ \\
\hline Min-Max & $0.9-1.9$ & $1.0-1.8$ & $0.9-1.9$ & $1.5-2.7$ & $1.3-2.1$ & $1.3-2.7$ \\
\hline $\mathbf{n}$ & 20 & 20 & 40 & 20 & 20 & 40 \\
\hline & \multicolumn{3}{|c|}{ Diameter of the AAN } & \multicolumn{3}{c|}{ DEP Diameter (AAN) } \\
\hline Mean & 0.5 & $0.5 \pm 0.1$ & $0.5 \pm 0.1$ & 0.9 & $1.0 \pm 0.2$ & $1.0 \pm 0.2$ \\
\hline Min-Max & $0,50-0,50$ & $0,42-0,67$ & $0,42-0,67$ & $0,95-0,95$ & $0,79-1,13$ & $0,79-1,13$ \\
\hline $\mathbf{n}$ & 1 & 3 & 4 & 1 & 3 & 4 \\
\hline
\end{tabular}

Table III: Distances (mm) from the Abducens Nerve (AN) to the Posterior Clinoid Process (PCP) and Petrous Apex (PA), and from the Accessory Abducens Nerve (AAN) to the Posterior Clinoid Process (PCP) and Petrous Apex (PA) in 20 Cadaveric Skulls

\begin{tabular}{|l|c|c|c|c|c|c|}
\hline & \multicolumn{3}{|c|}{ AN-PCP Distance } & \multicolumn{3}{c|}{ AN-PA Distance } \\
\hline & Right & Left & Both & Right & Left & Both \\
\hline Mean & $8.9 \pm 2.3$ & $7.8 \pm 2.6$ & $8.4 \pm 2.5$ & $3.7 \pm 1.9$ & $3.5 \pm 2.4$ & $3.6 \pm 2.1$ \\
\hline Min-Max & $5.5-15.1$ & $3.6-12.6$ & $3.6-15.1$ & $0.8-9.1$ & $0.7-10.8$ & $0.7-10.8$ \\
\hline n & 20 & 20 & 40 & 20 & 20 & 40 \\
\hline & \multicolumn{3}{|c|}{ AAN-PCP Distance } & \multicolumn{3}{c|}{ AAN-PA Distance } \\
\hline Mean & 7.4 & $9.1 \pm 5.0$ & $8.7 \pm 4.1$ & 5.6 & $5.4 \pm 4.5$ & $5.4 \pm 3.7$ \\
\hline Min-Max & $7.4-7.4$ & $5.7-14.8$ & $5.7-14.8$ & $5.6-5.6$ & $0.7-9.6$ & $0.7-9.6$ \\
\hline n & 1 & 3 & 4 & 1 & 3 & 4 \\
\hline
\end{tabular}

identification of a single or duplicated abducens nerve, along with recognition of neighboring surgical landmarks may reduce surgery-related complications (15). Preoperative meticulous assessment of MRI images may help delineate the anatomy and identify duplication of the AN (2).

Özveren et al. (31) classified the anatomical variations of the AN into six types: type 1 is a single trunk; type 2 is a single emergence from the brain stem, splitting before piercing the dura and and merging again after the carotid angulation before entering the orbit; type 3 is a double emergence from the brain stem, coursing double and reuniting after the carotid angulation; type 4 is a doubling of the nerve throughout its entire course. Type 5 is an aplastic nerve, and type 6 is triplication of the nerve in its cisternal and petroclival segments. Özveren et al. (31) found the incidence of duplication (types 2 and 3) to be $15 \%$. Nathan et al (28) also described the type 1,2, and 3 branching patterns of the $\mathrm{AN}$, and found a duplication incidence of $13.5 \%$, while Iocenetta et al. (15) found duplication to occur in $8 \%$ of specimens. Jain (16) is the only author to report a type 4 abducens nerve. We found the incidence of type 2 or type 3 variations to be $10 \%$, and did not encounter any type 4 variation. However, we found the incidence of branching (double and even triple) to be common (55\%). If types 2 and 3 are excluded, branching was still quite common (45\%). Branching at the intracavernous segment of the AN continued without merging in $7.5 \%$ of specimens. Umansky et al. (42) also found a high percentage of branching $(57.5 \%)$ among 40 specimens that is very close to our percentage. We believe that branching of the AN at the intracavernous segment is a result of carotid angulation that results in flattening of the nerve as seen in Figures 2, 3 and 4. In type 2 and 3 patterns, 
the AN branches enter the dura through separate entrance pores and travel separately with intervening tissue and then reunite. If this type of "branching" with intervening tissue is denoted branching, then we recommend that the branching anatomy of the AN at the cavernous portion which has no intervening tissue be labelled "pseudobranching". The term "duplication" may then be used in cases of AN duplication throughout its course. We think it would be better to describe "branching and its segment" of the AN qualitatively rather than by type, because of the high number of variations. Pseudobranching is perhaps caused by pressure of the ICA against the nerve at its angulation at the carotid angle. True "branching" and "duplication" are probably congenital (15).

Another important effect of nerve angulation is seen in the pathophysiology of $\mathrm{AN}$ paralysis. Angulation may increase the risk of nerve injury in some situations. The least pronounced angulation is where the AN pierces the dura and injury to the $\mathrm{AN}$ at this area can occur as a result of midfrontal impact $(5,39)$. In our study, the thickness of the AN in this region was found to be $1.3 \pm 0.2 \mathrm{~mm}$, which is narrower than the dural hole through which it passes $(1.8 \pm 0.3 \mathrm{~mm})$. Although the dural hole is larger than the nerve itself, fixation of the nerve may act as a fulcrum and cause nerve injury in cases of head trauma, even when no basilar skull fracture is present $(5,24)$. After piercing the dura, the main fixation point of the nerve is inside Dorello's canal. Dense adhesions between the dural sheath of the nerve and the endosteal dura of the petrous apex and petrosphenoidal ligament of Gruber are present (42). Paralysis of the AN, an indirect sign of intracranial hypertension, is a well-known false localizing sign of a brain tumour (42). Possible mechanisms responsible for AN paralysis include: 1) downward movement of the hindbrain causes the AN to be compressed by the sharp border of the petrous apex; 2) the AN, when it leaves the brain stem, is close to the sagittal plane, and this may make it vulnerable to injury if the brain stem shifts posteriorly; 3) compression of the nerve and underlying pons by lateral branches of the basilar artery, mainly the AICA; and 4) cerebral blood flow reduction causing brain stem ischemia may result in nuclear or neural ischemia, which might explain transient and recurring abducens weakness in cases of intracranial hypertension (44). Intracranial hypertension and withdrawal of CSF during lumbar puncture causes a caudal shift of the brain stem. Thus spinal procedures like lumbar puncture, contrast myelography, spinal anesthesia, and spinal shunting have been reported to cause abducens paralysis $(8,23,26,32,42)$. Abducens paralysis may also result from iatrogenic and spontaneous intracranial hypotension $(6,7,10,22)$. Intracranial hypertension, intracranial hypotension and cerebrospinal fluid withdrawal all share a common element; all result in downward displacement of the brain stem which in turn stretches the abducens nerve against its angles and fixations at the petrous apex. This is the apparent mechanism of paresis of the AN in these indirect situations. No other cranial nerve has a long intradural conduit with angulations and fixations such as the AN in Dorello's canal. Intracranial tumors may also cause AN paralysis without raising intracranial pressure (45). Skeletal traction for kyphoscoliosis, cervical hyperflexion and hyperextension injuries, and head trauma without skull fracture may also cause stretching and paresis of the nerve $(1,5,25,33,36,38,43)$. AN paresis has also been reported to occur during endovascular applications, because it lies close to the pathway of the catheter and may become damaged $(9,12,20,29,30)$. The risk for damage is especially high if the AN is located medially below the petrosphenoidal ligament of Gruber. In our study though, none were found in that location, but $12.5 \%$ passed below the middle third of the petrosphenoidal ligament. Umansky et al (42) found 9\% passage through the medial third, but Özveren et al. (30) found none; middle third passages in these studies were $52 \%$ and $43 \%$ respectively. The etiology of AN paralysis is clear in cases of local damage, such as petrous bone fracture, inflammatory lesions of the temporal bone, and compression from tumour or vascular structures at the petrous apex and cavernous portion of the nerve.

Microanatomical characteristics of abducens nerve are of interest for surgical approaches to the base of the skull. The anterior transpetrosal approach to the petroclival region has been described by Kawase et al for management of a variety of sphenopetroclival lesions $(17,18,19)$. In this approach, the petrous pyramid is exposed epidurally until trigeminal impression at the petrous rim is identified, with care given to not injure minor and major petrosal nerves. Maximal bone resection of the anterior petrous apex superior to the internal auditory canal, medial to major petrosal nerve and anterior to arcuate eminence, is 
then carried out. After mobilization of the $5^{\text {th }}$ cranial nerve, the dura of the middle fossa is opened while ensuring that the $4^{\text {th }}$ cranial nerve along the free edge of the tentorium is not disturbed. After dividing the superior petrosal sinus, the lesion in the petroclival region exposed for surgical manipulation. During removal of the tumour, particular attention must be paid to avoid damaging the AN (21). The nerve courses in the lateral third below the petrosphenoidal ligament of Gruber's in the majority of specimens. We found the AN to be located laterally in majority as Özveren et al (30) (82.5\% versus 57\%) but Umansky et al (42) found in middle location. The petrous tubercle attached by the PSL is the furthest limit for bone resection because the PSL protects the AN during bony resection in the anterior transpetrosal approach (30). But the nerve or one of its branches may be at risk in case of branching, in which case one of the branches may pass over the petrosphenoidal ligament $(13,15)$.

The abducens nerve is the longest cranial nerve and its many angles and fixations along its course put the nerve at risk for paresis in many indirect situations. We found branching of the abducens nerve in a significantly higher percentage of specimens than has previously been reported. The morphometric data regarding the abducens nerve reported in this study may be helpful to those evaluating diagnostic images and surgeons planning to operate in the region.

\section{REFERENCES}

1. Advani RM, Baumann MR: Bilateral sixth nerve palsy after head trauma. Ann Emerg Med 41(1):27-31, 2003

2. Alkan A, Sıgırcı A, Özveren MF, Kutlu R, Altınok T, Onal Ç, Sarac K: The cisternal segment of the abducens nerve in man: Three dimensional MR imaging. Eur J Radiol 51:218-222, 2004

3. Al-Mefty O: Supraorbital-pterional approach to skull base lesions. Neurosurgery 21:474-477, 1987

4. Antoniades K, Karakasis D, Taskos N: Abducens nerve palsy following transverse fracture of the middle cranial fossa. J Craniomaxillofac Surg 21:172-175, 1993

5. Arias MJ: Bilateral traumatic abducens nerve palsy without skull fracture and with cervical spine fracture: Case report and review of the literature. Neurosurgery 16:232-234, 1985

6. Beck J, Raabe A, Seifert V, Dettmann E: Intracranial hypotension after chiropractic manipulation of the cervical spine. J Neurol Neurosurg Psychiatry 74:821-822, 2003

7. Berlit P, Berg-Dammer E, Kuehne D: Abducens nerve palsy in spontaneous intracranial hypotension. Neurology 44:1552, 1994

8. Black PM, Chapman PH: Transient abducent paresis after shunting for hydrocephalus. J Neurosurg 55:467-469, 1981
9. Bonelli FS, Huston J III, Meyer FB, Carpenter PC: Venous subarachnoid hemorrhage after inferior petrosal sinus sampling for adrenocorticotropic hormone. Am J Neuroradiol 20:191-192, 1999

10. Ferrante E, Savino A, Brioschi A, Marazzi R, Donato MF, Riva M: Transient oculomotor cranial nerves palsy in spontaneous intracranial hypotension. J Neurosurg Sci 42:177-179, 1998

11. Hakuba A, Liu S, Niishimura S: The orbitozygomatic infratemporal approach: A new surgical technique. Surg Neurol 26:271-276, 1986

12. Halbach VV, Higashida RT, Hieshima GB, Hardin CW, Yang PJ: Transvenous embolization of direct carotid cavernous fistulas. Am J Neuroradiol 9:741-747, 1988

13. Iocenatta G, Fusco M, Cavallo LM, Cappabianca P, Samii M, Tschabitscher: The abducens nerve: Microanatomic and endoscopic study. Neurosurgery 61:7-14, 2007

14. Iocenatta G, Fusco M, Sami M: The sphenopetroclival venous gulf: A microanatomical study. J Neurosurg 99:366-375, 2003

15. Iocenatta G, Tessitore E, Samii M: Duplicated abducent nerve and its course: Microanatomical study and surgery related considerations. J Neurosurg 95:853-858, 2001

16. Jain KK: Aberrant roots of the abducens nerve. J Neurosurg 21:349-351, 1964

17. Kawase T, Toya S, Shiobara R: Anterior transpetrosaltranstentorial approach for sphenopetroclival lesions: Surgical method and results in ten patients. Neurosurgery 28:869-876, 1991

18. Kawase T, Toya S, Shiobara R: Middle fossa transpetrosaltranstentorial approaches for petroclival meningiomas: Selective pyramid resection and radicality. Acta Neurochir 129:113-120, 1994

19. Kawase T, Toya S, Shiobara R, Mine T: Transpetrosal transtentorial approach for aneurysms of basilar artery. J Neurosurg 63:857-861, 1985

20. King WA, Hieshima GB, Martin NA: Venous rupture during transvenous approach to a carotid cavernous fistula. J Neurosurg 71:133-137, 1989

21. Knosp E, Tschabitscher, Matula C, Koos WT: Modifications of temporal approaches: Anatomical aspects of a microsurgical approach. Acta Neurochir Suppl (Wien) 53:159-165, 1991

22. Kose KC, Cebesoy O, Karadeniz E, Bilgin S: Eye problem following foot surgery--abducens palsy as a complication of spinal anesthesia. MedGenMed 7:15, 2005

23. Kurbanyan K, Lessell S: Intracranial hypotension and abducens palsy following upper spinal manipulation. Br J Ophthalmol 92:153-155, 2008

24. Lazow SK, Izzo SR, Feinberg ME, Berger JR: Bilateral abducens nerve pulsy secondary to maxillofacial trauma: Report of a case with proposed mechanism of injury. J Oral Maxillofac Surg 53:1197-1199, 1995

25. Mac Even GD, Bunnel WP, Sriram K: Acute neurological complications in the treatment of scoliosis. A report of scoliosis research society. J Bone Joint Surg (Am) 57:404-408, 1975

26. Miller EA, Savino PJ, Schata NJ: Bilateral sixth nerve pulsy. A rare complication of water-soluble conrats myelography. Arch Ophthalmol 100:603-604, 1982

27. Nakagawa T, Uchida K, Ozveren MF, Kawase T: Abducens schwannoma inside the cavernous sinus proper: Case report. Surg neurol 61:559-563, 2004

28. Nathan H, Ouaknine G, Kosary IZ: The abducens nerve: Anatomical variations in its course. J Neurosurg 41:561-566, 1974 
29. OishiH, Arai H, Sato K, lizuka Y: Complications with transvenous embolization of cavernous dural arteriovenous fistula. Acta Neurochir (Wien) 141:1265-1271, 1999

30. Ozveren MF, Uchida K, Aiso S, Kawase T: Meningovenous structures of the petroclival region: Clinical importance for surgery and intravascular surgery. Neurosurgery 50:829-836, 2002

31. Özveren MF, Sam B, Akdemir İ, Alkan A, Tekdemir İ, Deda H: Duplication of the abducens nerve at the petroclival region: An Anatomic study. Neurosurgery 52:645-651, 2003

32. Perlman AM, Barry D: Bilateral sixth nevre palsy after watersoluble conrast myelography. Arch Ophthalmol 102:968, 1984

33. Rozario RA, Stein BM: Complications of halopelvic traction. Case report. J Neurosurg 45:716-717, 1976

34. Samii M, Ammirati M, Mahran A, et al: Surgery of petroclival meningiomas: Report of 24 cases. Neurosurgery 24:12-17, 1989

35. Samii M, Tatagiba M, Carvalho GA: Retrosigmoid intradural suprameatal approach to Meckel's cave and the middle fossa: Surgical technique and outcome. J Neurosurg 92:235-241, 2000

36. Schneider RC, Johnson FD: Bilateral traumatic abducens palsy. A mechanism of injury suggested by the study of associated cervical spine fracture. J Neurosurg 34:33-37, 1971

37. Sekhar LN, Schramm VL Jr, Jones NF: Subtemporalpreauricular infratemporal fossa approach to large lateral and posterior cranial base neoplasms. J Neurosurg 67:488-499, 1987
38. Shifrin LZ: Bilateral abducens nerve palsy after cervical spine extension injury. A case report. Spine (Phila Pa 1976) 16: 374-375, 1991

39. Tagaki H, Miyasaka Y, Kuramae T, et al: Bilateral traumatic abducens nerve palsy without skull fracture or intracranial hematoma: A report of 3 cases and consideration of mechanism of injury. No Shinkei Geka 4:963-969, 1976

40. Tekdemir İ, Deda H, Karahan ST, Arıncı K: The intracranial course of the abducens nerve. Turkish Neurosurgery 6:96-102, 1996

41. Umansky F, Elidan J, Valerezo A: Dorello's canal: A microanatomical study. J Neurosurg 75:294-298, 1991

42. Umansky F, Valarezo A, Elidan J: The microsurgical anatomy of the abducens nerve in its intracranial course. Laryngoscope 102:1285-1291, 1992

43. Uzan M, Hanci M, Sarioğlu AC, Kaynar MY, Bozkuș H: Bilateral traumatic abducens nerve paralysis with cervical spine flexion injury. Eur Spine J 5:275-277, 1996

44. Van Allen, MW: Transient recurring paralysis of ocular abduction: A syndrome of Intracranial hypertension. Arch Neurol 17:81-88, 1967

45. Ziyal IM, Bozkurt G, Bilginer B, Gülsen S, Özcan OE: Abducens nerve palsy in a patient with parasagital meningioma. Neurol Med Chir (Tokyo) 46:98-100, 2006 